\title{
The association of anti-CCP antibodies with disease activity in rheumatoid arthritis
}

\author{
Münevver Serdaroğlu • Haşim Çakırbay • \\ Orhan Değer $\cdot$ Sevil Cengiz $\cdot$ Sibel Kul
}

Received: 17 July 2007 / Accepted: 16 March 2008 / Published online: 17 April 2008

(C) The Author(s) 2008

\begin{abstract}
Antibodies to citrullinated proteins have been described in patients with rheumatoid arthritis (RA) and these appear to be the most specific markers of the disease. Our objective was to determine the frequency of antibodies to cyclic citrullinated peptides (CCPs) in patients with RA and the association of anti-CCP antibodies with disease activity, radiological erosions and HLA DR genotype. Forty patients with RA and 38 patients with fibromyalgia were included in this study. Serum samples were collected from both patient groups with RA and fibromyalgia. AntiCCP was measured by the corresponding enzyme-linked immunosorbent assay. Additionally, erythrocyte sedimentation rate (ESR), C-reactive protein (CRP), rheumatoid factor (RF), disease activity score (DAS), visual analog scala (VAS), HLA genotype and radiographic information were determined in patients with RA. The rate of sensitivity and specificity of anti-CCP reactivity for the diagnosis RA were measured (sensitivity $50 \%$, specificity $100 \%$ ). There is no significant difference between anti-CCP $(+)$ and antiCCP (-) RA patients for DAS28, VAS, ESR, CRP, disease duration, HLA genotype, and radiological assessment of hand. However, there was a significant difference between anti-CCP (+) and anti-CCP (-) RA patients for RF and the radiological assessment of left and right wrists (respectively,
\end{abstract}

M. Serdaroğlu $(\bowtie) \cdot$ H. Çakırbay

Physical Therapy and Rehabilitation,

Karadeniz Technical University, Trabzon, Turkey

e-mail: drmunser@yahoo.com

O. Değer $\cdot$ S. Cengiz

Biochemistry Department, Karadeniz Technical University,

Trabzon, Turkey

S. Kul

Radiology Department, Karadeniz Technical University,

Trabzon, Turkey
$P<0.05, P=0.04, P=0.01$ ). There was no significant correlation between anti-CCP antibody and ESR, CRP, VAS, DAS 28 or radiological assessment. A small but significant correlation was found between RF and anti-CCP antibody $(P=0.02, r=0.35)$.

Keywords Rheumatoid arthritis - Anti-CCP antibodies . Rheumatoid factor · Disease activity $\cdot$ Radiological erosions

\section{Introduction}

Rheumatoid arthritis (RA) is a systemic inflammatory disease characterized by chronic and erosive poliarthritis caused by abnormal growth of sinovial tissue or pannus, and causes irreversible joint disability. It is the most common inflammatory arthritis, affecting from 0.5 to $1 \%$ of the general population worldwide, with a female/male ratio of 2.5:1. The disease may appear at any age, but it is most common among those aged from 40 to 70 years and its incidence increases with age [1]. Apart from pain, RA is associated with reduction of functional capacity, and increased comorbidity and mortality [2,3].

For decades, the diagnosis of RA has been primarily based on clinical manifestations. However, especially during the first few months of the disease, the 1987 revised criteria of the American College of Rheumatology (ACR) are rarely met [4]. About one-third of the patients with persistent arthritis do not fulfill the classification criteria, so it is often difficult to diagnose RA in the very early stages of the disease [5]. On the other hand, numerous studies have shown that substantial irreversible joint damage occurs within the first 2 years $[6,7]$. In many cases, irreversible damage of the joint cartilage has already occurred by the 
time laboratory and radiological parameters have confirmed the clinical daignosis RA [8].

Because of the highly variable and unpredictable course of the disease, current therapeutic strategies in RA are increasingly aggressive regimens early in the course of the disease. Therefore, diagnostic tests with high-specificity are desirable for deciding on the optimal treatment [9].

So far, serological support in the diagnosis of RA was mainly based on the presence of rheumatoid factors (RF) [10]. RF can be detected in up to 70-80\% of RA patients [11]. The ACR criteria for RA diagnosis include the presence of RF, a decision that has contributed to the widely routine use of this test as a diagnostic marker for RA in most clinical laboratories. However, these antibodies are not very specific for RA and can also be detected in other rheumatic diseases, infectious diseases, and even in 3-5\% of apparently healthy individuals [10, 12].

In recent years, many studies on antibodies against cyclic citrullinated peptide (CCP) have demonstrated that these antibodies are highly specific and predictive for RA [13] that they can be detected years before onset [14], and also that they are associated with joint destruction [15]. Furthermore, the presence or absence of these antibodies seems to be a stable trait [16]. Anti-CCP antibodies are detected in SE-positive as well as in SE-negative RA patients. Carriership of SE alleles in RA is associated with the presence of anti-CCP antibodies [17].

This article investigates the sensitivity and specificity of the anti-CCP antibody in RA and association of it antibody with disease activity and radiological findings.

\section{Materials and methods}

This study was conducted in the outpatient rheumatology unit of the Karadeniz Technical University Medical Faculty, Türkiye. Forty women patients with RA (median age, 48.3 years, range 22-74) who met at least four 1987 American College of Rheumatology (ACR) criteria and 38 women patients with fibromyalgia (median age 44, range31-60), who were considered as control group, were included in this study. Serum samples were obtained from both patient groups with fibromyalgia and RA and were aliquoted and stored at $-80^{\circ} \mathrm{C}$ until assayed. Additionally, erythrocyte sedimentation rate (ESR), C-reactive protein (CRP), rheumatoid factor (RF), disease activity score 28 (DAS), visual analog scala (VAS), and human leukocyte antigen (HLA) genotype were recorded in patients with rheumatoid arthritis. Hand radiographs were taken at the beginning of study and radiological assessment was performed by Larsen score.

Serum antibodies directed to the cyclic citrullinated peptide (anti-CCP) were assessed with a commercial enzyme-linked immunosorbent assay (ELISA), (Aida gmbh, Germany, RA/CP detect, Ref 10165) and it was considered as positive if the antibody titer was greater than $15 \mathrm{U} / \mathrm{ml}$.

These results were analyzed by SPSS (version 11.5). Student's $t$ test for continuous variables was used to examine the significance of differences between the different groups. Non-parametric Mann-Whitney test was used to compare non-paired sets. $P$-value less than 0.05 was regarded as significant. Correlation between variables was assessed by Spearman's correlation coefficient and Pearson correlation.

\section{Results}

The anti-CCP test demonstrated a specificity of $100 \%$ and sensitivity of $50 \%$ for RA when compared with controls. The sociodemographic and disease-related characteristics of the patient with rheumatoid arthritis were summarized in Table 1. The mean \pm SD age of the patients was $48.3 \pm$ 12.8 years, and all of them were females. The most common treatments received included combination of methotrexate (MTX), sulfosalazine (SSZ) and deltacortril

Table 1 Sociodemographic and disease related characteristics of 40 patients with rheumatoid arthritis

\begin{tabular}{ll}
\hline Characteristics & \\
Age, mean \pm SD years & $48.3 \pm 12.8$ \\
BMI, mean \pm SD & $26.9 \pm 4.4$ \\
Female & $40(100)$ \\
RF, mean \pm SD & $103.5 \pm 154$ \\
Anti-CCP, mean \pm SD $(\mathrm{U} / \mathrm{ml})$ & $104.6 \pm 132.2$ \\
DAS28, mean \pm SD & $3.9 \pm 1.3$ \\
Remission & $5(12.5)$ \\
Low activity & $5(12.5)$ \\
Median activity & $20(50)$ \\
High activity & $10(25)$ \\
Disease duration \pm years & $6.8 \pm 6.6$ \\
ESR, mean \pm SD $(\mathrm{mm} / 1 \mathrm{st} \mathrm{h})$ & $29.2 \pm 22.9$ \\
RF & $26 / 40(65)$ \\
HLADR3 & $4 / 36(11.1)$ \\
HLADR4 & $10 / 36(27.8)$ \\
VAS, mean \pm SD & $4.8 \pm 1.7$ \\
CRP, mean \pm SD (mg/l) & $1.9 \pm 3.0$ \\
Drug treatment & \\
MTX/DTC & $11(27.5)$ \\
SSZ/DTC & $7(17.5)$ \\
MTX/SS/DTC & $13(32.5)$ \\
MTX/HQC/DTC & $2(5)$ \\
NSAID & $7(17.5)$ \\
\hline
\end{tabular}

* Except where indicated otherwise, values are the number (\%) 
(DTC) (32.5\%), followed by the combination of methotrexate and deltacortril (27.5\%), sulfasalazine and deltacortril (17.5\%), nonsteroidal anti-inflammatory drugs $(17.5 \%)$ and MTX-hydroxychloroquine (HCQ) (5\%). On average, disease duration (S.D.) was $6.8 \pm(6.6)$ years. RF was positive in $26(65 \%)$ patients and negative in $14(35 \%)$ patients. The anti-CCP was positive in $20(50 \%)$ patients and negative in $20(50 \%)$ patients. The mean \pm SD titer of the anti-CCP was $104.6 \pm 132.2 \mathrm{U} / \mathrm{ml}$. The distribution of anti-CCP titers was demonstrated in Fig. 1. HLA genotypes of the four patients could not be studied. Five (12.5\%) patients were in remission. In five (12.5\%) patients, DAS 28 was low, in 20 patients it was median, and in ten patients severely active.

In 18/20 patients (90\%) with anti-ccp positive and in 8/ 20 patients $(40 \%)$ with anti-CCP negative, RF was positive and there were significant differences between anti-CCP positive and negative patients for rheumatoid factor $(P<0.05)$ (Table 2$)$. The analysis of serological parameters of disease activity (ESR, CRP, DAS 28 and VAS) and disease duration between the anti-CCP positive and negative patients with rheumatoid arthritis showed no significant difference in any parameter $(P>0.05)$. According to radiological assessment of hand radiography by Larsen score (0-100), there was no significant difference between the anti-CCP positive and negative patients with RA. However, the analysis of wrist radiography $(0-5)$ between the anti-CCP positive and negative patients with RA showed significant difference with a higher score in anti-

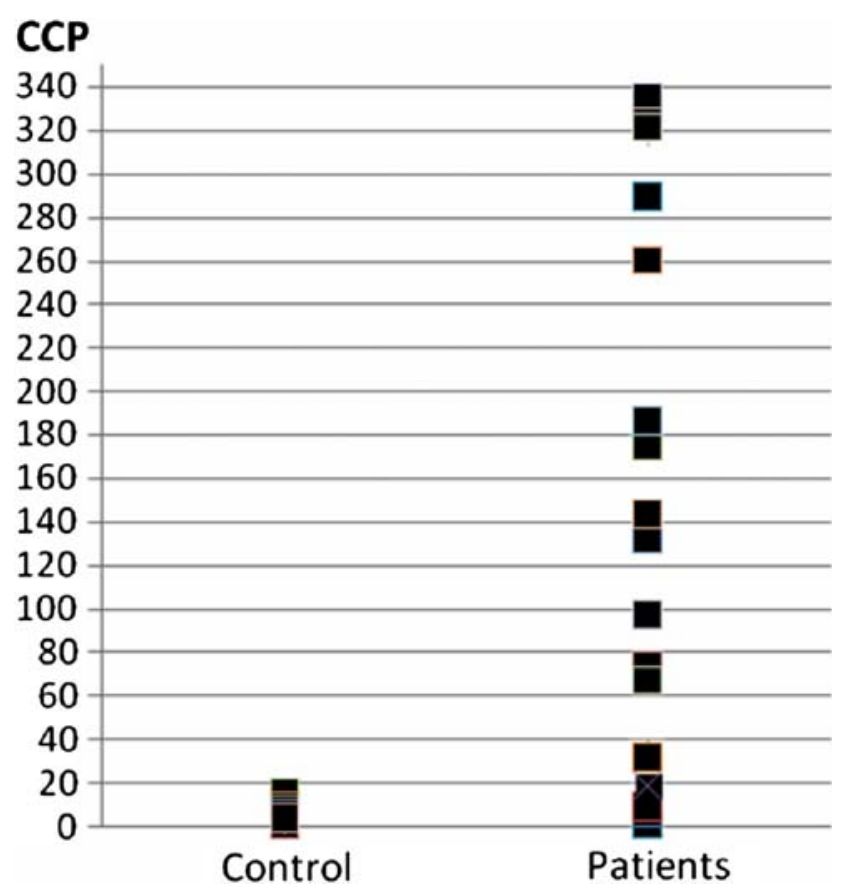

Fig. 1 The disturbance of the titers of anti-CCP antibodies in control group and patients with RA
Table 2 Difference in the serological parameter in the CCP-negative versus CCP-positive patients with RA

\begin{tabular}{llll}
\hline & $\begin{array}{l}\text { Anti-CCP positive } \\
\text { patients }(n=20)\end{array}$ & $\begin{array}{l}\text { Anti-CCP negative } \\
\text { patients }(n=20)\end{array}$ & $P$-value \\
\hline Age & $47.2 \pm 14.5$ & $49.5 \pm 11$ & 0.593 \\
ESR & $25.9 \pm 19.4$ & $32.5 \pm 26$ & 0.373 \\
CRP & $1.5 \pm 2.4$ & $2.2 \pm 3.7$ & 0.440 \\
Disease duration & $7.4 \pm 7.5$ & $6.2 \pm 5.7$ & 0.614 \\
VAS & $5.1 \pm 1.7$ & $4.5 \pm 1.6$ & 0.313 \\
DAS28 & $4.1 \pm 1.3$ & $3.8 \pm 1.4$ & 0.459 \\
RF $(+)$ & $18 / 20(90)$ & $8 / 20(40)$ & 0.001 \\
HLADR3 $(+)$ & $1 / 19(5.3)$ & $3 / 19(17.6)$ & 0.258 \\
HLADR4 $(+)$ & $4 / 15(21.1)$ & $6 / 17(35.3)$ & 0.341 \\
\hline
\end{tabular}

Table 3 Difference in the radiologic assessment of hand and wrist by Larsen score in CCP-negative versus CCP-positive patients with RA

Anti-CCP positive Anti-CCP negative $P$-value patients $(n=20) \quad$ patients $(n=20)$

\begin{tabular}{lccc}
\hline $\begin{array}{l}\text { Rigt hand score, } \\
\text { mean } \pm \text { SD }\end{array}$ & $12.7 \pm 8.4$ & $8.2 \pm 5.6$ & 0.051 \\
$\begin{array}{l}\text { Right wrist score, } \\
\text { mean } \pm \text { SD }\end{array}$ & $2.4 \pm 1.5$ & $1.4 \pm 1.3$ & 0.010 \\
$\begin{array}{c}\text { Left hand score, } \\
\text { mean } \pm \text { SD }\end{array}$ & $11.2 \pm 7.8$ & $10.0 \pm 7.6$ & 0.362 \\
$\begin{array}{l}\text { Left wrist score, } \\
\text { mean } \pm \text { SD }\end{array}$ & $2.3 \pm 2.3$ & $1.4 \pm 1.3$ & 0.044 \\
\hline
\end{tabular}

CCP positive patients $(P<0.05)$ (Table 3$)$. There was also no significant correlation between anti-CCP antibody and ESR, CRP, VAS, DAS 28 or radiological assessment. A small but significant correlation was found between RF and anti-CCP antibody ( $r=0.3, P=0.02)$ (Table 4; Fig. 2). Additionally, there was a significant correlation between DAS 28 and RF, ESR, CRP, VAS, radiological assessment of right wrist or left wrist $(r=0.3, P=0.03 ; r=0.6$, $P<0.005 ; r=0.4, P<0.005 ; r=0.7, P<0.005 ; r=0.3$, $P=0.03 ; r=0.4, P=0.02$, respectively) (Table 5).

\section{Discussion}

The modern trend of RA treatment has been changed to start treatment as early as possible, based on the concept that early control of inflammation results in reduced joint damage [18]. It therefore is important to differentiate between RA and other forms of arthritis early after the onset of symptoms [19, 20]. Although the 1987 American College of Rheumatology classification criteria for RA [4] are often used in clinical practice as diagnostic tool for RA, they are not very well suited for the diagnosis of early RA 
Table 4 The correlation between anti-CCP and other parameters of disease activity

\begin{tabular}{lcl}
\hline & $X \pm \mathrm{SD}$ & Anti-CCP \\
\hline ESR & $29.2 \pm 22.9$ & $P=0.54$ \\
& & $r=-0.11$ \\
CRP & $1.9 \pm 3.0$ & $P=0.46$ \\
& & $r=-0.1$ \\
VAS & $4.8 \pm 1.7$ & $P=0.09$ \\
& & $r=-0.02$ \\
DAS 28 & $3.9 \pm 1.3$ & $P=0.63$ \\
Left hand & & $r=0.07$ \\
Right hand & $8.9 \pm 7.6$ & $P=0.75$ \\
& & $r=0.05$ \\
Left wrist & $8.1 \pm 5.6$ & $P=0.37$ \\
& & $r=0.14$ \\
Right wrist & $1.3 \pm 1.2$ & $P=0.49$ \\
RF & $1.3 \pm 1.2$ & $r=0.11$ \\
& & $P=0.10$ \\
& & $r=0.26$ \\
& & $P=0.02$ \\
& & $r=0.35$ \\
\hline
\end{tabular}

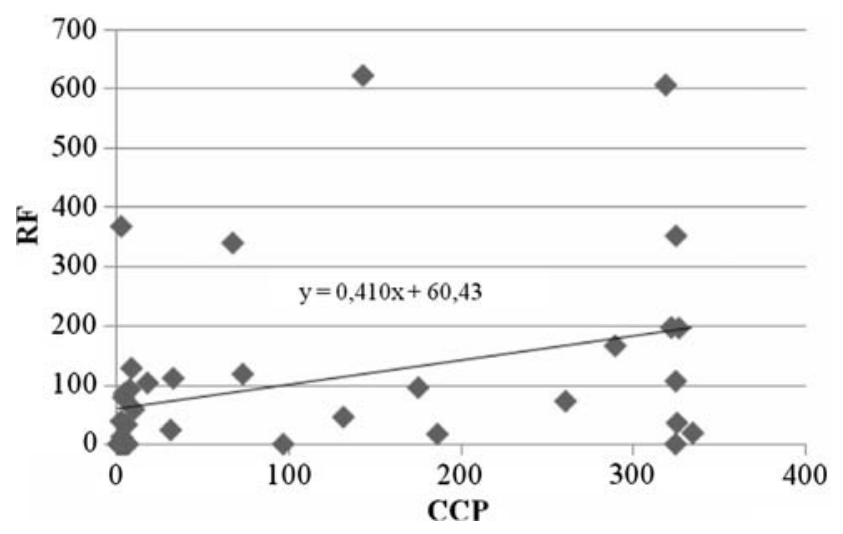

Fig. 2 The correlation between anti-CCP antibodies and RF

[21-23]. The ACR criteria rely heavily on the expression of clinical symptoms of RA, but in early RA these clinical parameters are often not (yet) manifest. Therefore, a specific and sensitive (serological) marker, which is present very early in the disease, is needed. Rheumatologists need to be able to target the use of potentially toxic and expensive drugs to those patients, where the benefits clearly outweigh the risks $[23,24]$. Therefore a good marker should ideally be able to predict the erosive or nonerosive progression of the disease.

In patients with RA, we found a sensitivity of $50 \%$ and specificity of $100 \%$ for anti-CCP. Schellekens et al. [25] reported that ELISA methods using the cyclic citrullinated peptide (CCP-ELISA), in a series of 149 RA and 312
Table 5 The correlation of DAS-28 with other parameters of disease activity

\begin{tabular}{lll}
\hline & $X \pm$ SD & DAS 28 \\
\hline RF & $103.4 \pm 154.1$ & $P=0.03$ \\
& $29.2 \pm 22.9$ & $r=0.3$ \\
ESR & $1.9 \pm 3.0$ & $P<0.005$ \\
& & $r=0.6$ \\
CRP & $4.8 \pm 1.7$ & $P<0.005$ \\
& & $r=0.4$ \\
VAS & $1.3 \pm 1.2$ & $P<0.005$ \\
& & $r=0.7$ \\
Right wrist & & $P=0.03$ \\
& $1.3 \pm 1.2$ & $r=0.3$ \\
Left wrist & & $P=0.02$ \\
& & $r=0.4$ \\
\hline
\end{tabular}

control sera, had a diagnostic sensitivity of $48 \%$ for a specificity of $96 \%$. Kroot et al. [26] identified $66 \%$ positive RA serum samples with CCP-ELISA. Lee and Schur [27] found a sensitivity of $66 \%$ and specificity of $90.4 \%$. Dubucquoi et al. [28] describe a sensitivity of $85 \%$ and a specificity of $90.9 \%$ for anti-CCP. Although the specificity of anti-CCP antibodies in RA is more than $90 \%$ in almost all reports, the prevalence (sensitivity) of the same antibodies ranges from 33 to $87.2 \%$. Such a discrepancy in sensitivity might reflect different cutoff levels, racial and genetic backgrounds, as well as the differences of used antigens and detection techniques among reports [29]. Another important point concerning the diagnostic value of $\mathrm{CCP}$ is that about 35-40\% of the RF-negative RA patients score positively for anti-CCP. In our study, only $2 / 14$ (14.3\%) patients with RF-negative RA were positive for anti-CCP antibodies and $12 / 14(85.7 \%)$ patients with RA were negative.

The value of anti-CCP antibodies and RF for predicting the outcome of RA, clinical signs of disease activity, and the severity of radiographic joint damage has been investigated recently. The studies by van Jaarsveld et al. [30], Kroot et al. [26] and Meyer et al. [15], all support the thesis that RA patients, positive for CCP, develop significanly more radiological damage than CCP-negative patients. Lately, Visser et al. [31] assessed a clinical prediction model in early RA patients for the three forms of arthritis outcome: self-limiting, persistent nonerosive and persistent erosive arthritis in which CCP was strongly associated with erosive arthritis, more than RF. Forslind et al. [32] reported the role of Anti-CCP in the radiological outcome in 379 cases with early RA, and concluded that anti-CCP as well as the baseline Larsen score and ESR was an independent predictor of radiological damage and progression in multiple regression analysis. In our study, CCP positive patients 
had a higher radiological score than CCP negative patients for radiological assessment of wrist by Larsen method. However, there was no significant difference for radiological assessment of hand by Larsen score.

In addition to the predictive value of CCP concerning radiological damage, Kastbom et al. [16] showed that CCP is good predictor of disease activity. CCP was even better than RF in predicting disease activity over 3 years after the diagnosis of recent onset of RA. Bas et al. showed an association of IgA RF and anti-CCP with clinical signs of disease activity $[33,34]$. The high prevalance of anti-CCP in RA patients with extensive disease activity and severe radiological changes, and even more impressively in RA patients who are IgM-RF-negative, suggests that anti-CCP is more useful than the RF alone in the early prediction of disease outcome and disease activity. We found a significant correlation between DAS 28 and RF, ESR, CRP, VAS, radiological assessment of right wrist or left wrist.

There is extensive evidence for the association between certain frequently occurring HLA-DRB1 alleles, the socalled "shared epitope" (SE)-encoding alleles (DRB1*0101, *0102, *0104, *0401, *0404, *0405, *0408, *0413, *0416, and $* 1001$ ), and susceptibility to RA [35]. Recently, it has been reported that the combination of anti-CCP antibodies and HLA-DRB1 locus antigens is strongly associated with more severe disease progressions [17, 36]. Most recent analyses [37] suggested that the primary association of SE alleles is with the development of erosions, especially in RF-negative individuals [38, 39].

In our study, we could not find correlation between antiCCP antibody and the serological markers of disease activity (ESR, DAS 28, CRP). There was a small, but significant positive correlation with anti-CCP and RF. Furthermore, we could find no significant difference between anti-CCP negative and anti-CCP-positive patients comparing ESR, CRP, HLA genotype, DAS. However, there was a significant differences between anti-CCP (+) and anti-CCP (-) RA patients for RF.

In conclusion, early development of erosive disease in RA is associated with the presence of several autoantibodies and the IgM RF is stil mostly used as a screening marker in the diagnosis of RA. However, the anti-CCP antibody assays have a comparable sensitivity in the diagnosis of RA but a much higher specifity. Further research, however, will be necesssary to elucidate the exact mechanism and the significance of protein citrullination in etiopathogenesis of RA.

Open Access This article is distributed under the terms of the Creative Commons Attribution Noncommercial License which permits any noncommercial use, distribution, and reproduction in any medium, provided the original author(s) and source are credited.

\section{References}

1. Lee DM, Weinblatt ME (2001) Rheumatoid arthritis. Lancet 358:903-911

2. Pincus T, Callahan LF, Sale WG, Brooks AL, Payne LE, Vaughn WK (1984) Severe functional declines, work disability, and increased mortality in seventy-five rheumatoid arthritis patients studied over nine years. Arthritis Rheum 27:864-872

3. Goodson N (2002) Coronary artery disease and rheumatoid arthritis. Curr Opin Rheumatol 14:115-120

4. Arnett FC, Edworthy SM, Bloch DA, McShane DJ, Fries JF, Cooper NS et al (1988) The American Rheumatism Association 1987 revised criteria for the classification of rheumatoid arthritis. Arthritis Rheum 31:315-324

5. Vallbracht I, Helmke K (2005) Additional diagnostic and clinical value of anti-cylic citrullinated peptide antibodies compared with rheumatoid factor isotypes in rheumatoid arthritis. Autoimmunity Rev 4:389-394

6. Mottonen TT (1988) Prediction of erosiveness and rate of development of new erosions in early rheumatoid arthritis. Ann Rheum Dis 47:648-653

7. van der Heijde DM (1995) Joint erosions and patients with early rheumatoid arthritis. Br J Rheumatol 34 (Suppl 2):1-8

8. Gough AK, Lilley J, Eyre S, Holder RL, Emery P (1994) Generalised bone loss in patients with early rheumatoid arthritis. Lancet 344:23-27

9. Olsen NJ, Stein CM (2004) New drug for rheumatoid arthritis. N Engl J Med 350:2167-2179

10. Eggeland T, Munthe E (1983) The role of the laboratory in rheumatology, rheumatoid factors. Clin Rheum Dis 9:135-160

11. Smolen JS (1996) Autoantibodies in rheumatoid arthritis. In: van Venrooij WJ, Maini RN, (eds) Manual of biological markers of disease, Section C1.1/1-C1.1/18. Kluwer, Dordrecht

12. Thorsteinsson J, Bjfrnsson OJ, Kolbeinsson A, Allander E, Sigfusson N, Olafsson O (1975) A population study of rheumatoid factor in Iceland. A 5 year follow-up of 50 women with rheumatoid factor (RF). Ann Clin Res 7:183-194

13. Van Gaalen FA, Linn-Rasker SP, van Venrooij WJ, de Jong BA, Breedveld FC, Verweij CL et al (2004) Autoantibodies to cyclic citrullinated peptides predict progression to rheumatoid arthritis in patients with undifferentiated arthritis: a prospective cohort study. Arthritis Rheum 50:709-715

14. Rantapaa-Dahlqvist S, de Jong BA, Berglin E, Hallmans G, Wadell G, Stenlund $\mathrm{H}$ et al (2003) Antibodies against cyclic citrullinated peptide and $\operatorname{IgA}$ rheumatoid factor predict the development of rheumatoid arthritis. Arthritis Rheum 48:2741-2749

15. Meyer O, Labarre C, Dougados M, Goupille P, Cantagrel A, Dubois A et al (2003) Anticitrullinated protein/peptide antibody assays in early rheumatoid arthritis for predicting five year radiographic damage. Ann Rheum Dis 62:120-126

16. Kastbom A, Strandberg G, Lindroos A, Skogh T (2004) Anti-CCP antibody test predicts the disease course during 3 years in early rheumatoid arthritis (the Swedish TIRA project). Ann Rheum Dis 63:1085-1089

17. van Gaalen FA, van Aken J, Huizinga TW, Schreuder GM, Breedveld FC, Zanelli E et al (2004) Association between HLA class IIgenes and autoantibodies to cyclic citrullinated peptides (CCPs) influences the severity of rheumatoid arthritis. Arthritis Rheum 50:2113-2121

18. Emery P (1994) The optimal management of early rheumatoid disease: the key to preventing disability. Br J Rheumatol 33:765768

19. Lindovist E, Eberhardt K, Bendtzen K et al (2005) Prognostic laboratory markers of joint damage in rheumatoid arthritis. Ann Rheum Dis 64:196-201 
20. Visser H (2005) Early diagnosis of rheumatoid arthritis. Best Pract Res Clin Rheumatol 19:55-72

21. Kaarela K, Kauppi MJ, Lehtinen KE (1995) The value of the ACR 1987 criteria in very early rheumatoid arthritis. Scand J Rheumatol 24:279-281

22. Saraux A, Berthelot JM, Chales G, Le Henaff C, Thorel JB, Hoang S et al (2001) Ability of the American College of Rheumatology 1987 criteria to predict rheumatoid arthritis in patients with early arthritis and classification of these patients two years later. Arthritis Rheum 44:2485-2491

23. van Venrooij WJ, Hazes JM, Visser H (2002) Anticitrullinated protein/peptide antibody and its role in the diagnosis and prognosis of early rheumatoid arthritis. Neth J Med 60:383-388

24. Kirwan JR, Quilty B (1997) Prognostic criteria in rheumatoid arthritis: can we predict which patients will require specific antirheumatoid treatment? Clin Exp Rheumatol 15(Suppl 17):S15S25

25. Schellekens GA, Visser H, de Jong BA, van den Hoogen FH, Hazes JM, Breedveld FC, van Venrooij WJ (2000) The diagnostic properties of rheumatoid arthritis antibodies recognizing a cyclic citrullinated peptide. Arthritis Rheum 43:155-163

26. Kroot EJ, de Jong BA, van Leeuwen MA, Swinkels H, van den Hoogen FH, van't Hof M, van de Putte LB, van Rijswijk MH, van Venrooij WJ, van Riel PL (2000) The prognostic value of anti-cyclic citrullinated peptide antibody in patients with recent-onset rheumatoid arthritis. ArthritisRheum 43:1831-1835

27. Lee DM, Schur PH (2003) Clinical utility of the anti-CCP assays in patients with rheumatic diseases. Ann Rheum Dis 62:870-874

28. Dubucquor S, Solau-Gervars E, Lefranc D et al (2004) Evaluation of anti-citrullinatedfilagrin antibodies as hallmarks for the diagnosis of rheumatic diseases. Ann Rheum Dis 63:415-419

29. Mimori T (2005) Clinical significance of anti-CCP antibodies in rheumatoid arthritis. Intern Med 44:1112-1126

30. van Jaarsveld CHM, ter Borg EJ, Jacobs JWG, Schellekens GA, Gmeling-Meyling FHJ, van Booma-Frankfort C et al (1999) The prognostic value of the antiperinuclear factor, anticitrullinated peptide antibodies and rheumatoid factor in early rheumatoid arthritis. Clin Exp Rheumatol 17:689-697
31. Visser H, le Cessie S, Vos K, Breedveld FC, Hazes JMW (2002) How to diagnose rheumatoid arthritis early. A prediction model for persistent (erosive) Arthritis. Arthritis Rheum 46:357-365

32. Forslind K, Ahlmen M, Eberhardt K, Hafstrom I, Svensson B (2004) BARFOT Study Group. Prediction of radiological outcome in early reumatoid arthritis in clinic paractice, role of antibodies to citrullinated peptides (anti-CCP). Ann Rheum Dis 63:1090-1095

33. Bas S, Perneger T.V, Seitz M et al (2002) Diagnostic tests for rheumatoid arthritis: comparison of anti-cyclic citrullinated peptide antibodies, anti-keratin antibodies and IgM rheumatoid factors. Rheumatology 41:809-814

34. Bas S, Genevay S, Meyer O, Gabay C (2003) Anti-cyclic citrullinated peptide antibodies, IgM and IgA rheumatoid factors in the diagnosis and prognosis of rheumatoid arthritis. Rheumatology 42:677-680

35. Gregersen PK, Silver J, Winchester RJ (1987) The shared epitope hypothesis: an approach to understanding the molecular genetics of susceptibility to rheumatoid arthritis. Arthritis Rheum 30:120513. (discussion-HLA DR)

36. Berglin E, Padyukov L, Sundin U, Hallmans G, Stenlund H, Van Venrooji WJ et al (2004) A combination of autoantibodies to cylic citrullinatedpeptide (CCP) and HLA-DRB1 locus antigens iss strogly associated with future onset of rheumatoid arthritis. Arthritis Res Ther 6(4):R303-R308

37. Gorman JD, Lum RF, Chen JJ, Suarez-Almazor ME, Thomson G, Criswell LA (2004) Impact of shared epitope genotype and ethnicity on erosive disease: a meta-analysis of 3,240 rheumatoid arthritis patients. Arthritis Rheum 50:400-412

38. El-Gabalawy HS, Goldbach-Mansky R, Smith D II, Arayssi T, Bale S, Gulko P, Yarboro C, Wilder RL, Klippel JH, Schumacher HR Jr (1999) Association of HLA alleles and clinical features in patients with synovitis of recent onset. Arthritis Rheum 42:16961705

39. Harrison B, Thomson W, Symmons D, Ollier B, Wiles N, Payton T, Barrett E, Silman A (1999) The influence of HLA-DRB1 alleles and rheumatoid factor on disease outcome in an inception cohort of patients with early inflammatory arthritis. Arthritis Rheum 42:2174-2183 